\title{
Cadmium-induced response of protein profile and antioxidant enzymes in aquatic macrophytes Myriophyllum spicatum and Ceratophyllum demersum
}

\author{
A. A. El-Khatib ${ }^{1}$, A. K. Hegazy ${ }^{2}$, Amany Abo-El-Kassem ${ }^{1}$ \\ ${ }^{1}$ Department of Botany, Faculty of Science, Sohag University, Egypt. ${ }^{2}$ Department of Botany, Faculty \\ of Science, Cairo University, Egypt
}

Rec. 3 Dec, 2011 Accpt. 26 Dec, 2011

\begin{abstract}
The aquatic species Ceratophyllum demersum and Myriophyllum spicatum were grown in a hydroponic system to analyze the activity of antioxidant enzymes and protein response under different cadmium concentrations. The behavior of the studied antioxidant enzymes (APX and POD) was affected by Cd-exposure and exhibited to some extent different activity. In comparison with control, the activity of APX and POD varied significantly $(P<0.01)$ among Cd-treatments, where the increase in Cd-concentration coupled with an initial increase in the activity of both antioxidant enzymes and subsequent Cd-treatments caused a decline in the activity. Generally, the activity of APX found to be more pronounced in M. spicatum (4-8 fold of control) in comparison to $C$. demersum. The treated plants exhibited different protein patterns depending on the plant species, Cd- concentration and time of exposure. Protein synthesis appears to be more sensitive to cadmium in C. demersum, than other plants where, appearance of high molecular weight $(138,127,112,109$ and $100 \mathrm{kDa})$ protein at $25 \mathrm{mg} / \mathrm{L}$ $\mathrm{Cd}$, disappearance of $38 \mathrm{kDa}$ proteins was recorded in all sets of experiment.
\end{abstract}

Keywords: Protein pattern, POD, APX, biomarker, metal toxicity

\section{Introduction}

Heavy metal tolerant plants have efficient mechanisms for restricting excessive metal concentrations in metabolically active compartments of the cells (Salt et al., 1999; Wójcik et al., 2005; Ma et al., 2005; Ueno et al., 2005). However, some metal ions are likely to remain in the cytoplasm and induce oxidative stress via generation of reactive oxygen species (ROS), which will hinder cell metabolism (Foyer et al.,1994). To protect themselves against these toxic oxygen intermediates, plant cells and its organelles like chloroplast, mitochondria and peroxisomes employ antioxidant defense systems. A great deal of research has established that the induction of the cellular antioxidant machinery is important for protection against various stresses (Tuteja, 2007; Khan and Singh, 2008; Singh et al., 2008; Gill et al., 2011). Prevention of oxidative stress by scavenging ROS is actively performed by antioxidative systems, which comprise antioxidant enzymes, such as catalase, peroxidases, superoxide dismutase and glutathione reductase (GR), as well as non-enzymatic antioxidants, such as glutathione (GSx) (El-Khatib et al., 2004; Vitória et al., 2001; Gratão et al., 2005; Tamás et al., 2008). Evidence exists that antioxidative defense plays an important role also in hyperaccumulators, as changes in the activities of different antioxidative enzymes were observed in hyperaccumulating plants in response to heavy metals treatments (Boominathan and Doran, 2003; Wójcik et al., 2006). In addition, heavy metal phytotoxicity is controlled by a number of factors, including the element's uptake site, bioavalability, competition for binding sites and ionic speciation (Ralph and Burchett, 1998; Panda and Choudhury, 2005).

Cadmium (Cd) is a widespread nonessential toxic heavy metal (HM), mainly released into the environment by power stations, heating systems, metal-working industries, waste incinerators, urban traffic, cement factories and as a by-product of phosphate fertilizers (Sanita' di Toppi and Gabbrielli, 1999). Cadmium emitted into the environment can have significant biological and ecological effects on higher plants,

\footnotetext{
* Corresponding author:

Dr. A.A. El-Khatib
}

$\bowtie$ aaelkhatib@yahoo.com 
which they protect themselves from $\mathrm{Cd}$ stress by a number of additive and/or synergic response mechanisms (Sanita' di Toppi and Gabbrielli, 1999). A frequent outcome following exposure to $\mathrm{Cd}$ pollution is the overproduction of reactive oxygen species (ROS), potentially causing oxidative damage in plant cells and thus requiring the intervention of antioxidant defense systems (Sandalio et al., 2001).

Aquatic macrophytes have proved to possess high metal binding capacities (Schiewer and Volesky, 2000). due to the presence of polysaccharides, proteins or lipid on the surface of their cell walls containing some functional groups such as amino, hydroxyl, carboxyl and sulphate, which can act as binding sites for metals (Holan and Volesky, 1994; Yu et al., 1999). Hence, aquatic plants are often the first link in relation to metal contents of aquatic environments. Myriophyllum spicatum L. (family Haloragidaceae) and Ceratophyllum demersum L. (family Ceratophyllaceae) are two perennial aquatic macrophytes spread all over the world and considered noxious and extremely invasive for freshwater environments. These species carry out their entire life cycle completely submerged. Both the above species take up metals from water, producing an internal concentration several folds greater than their surroundings and showing much higher metal-accumulating capacity and rate than nonhyperaccumulating terrestrial plants (ElKhatib and El-Sawaf, 2001). Despite the intensive work on aquatic macrophytes for their potential use in phytoremediation, the relative contribution of the diverse mechanisms leading to metal detoxification and tolerance, as well as the interspecific differences in defense strategies, have been given scanty consideration so far. For this reason, the present work was planned to test the hypothesis that induction of antioxidant enzymes APX and POD, as well as changes in protein profiles represent compensatory mechanisms developed by the studied species due to Cd detoxification.

\section{Material and Methods}

\section{Plant material, growth conditions and cadmium treatment}

The two studied species ( $C$. demersum and M.spicatum) were taken from the main stream of the River Nile bank. They exposed to different cadmium concentrations under controlled conditions of hydroponic cultures that similar to those of their original environment. One hundred gram from each healthy bi-distilled water pre rinsing species was transported onto the hydroponic cultures. They were kept for two weeks in Hoagland nutrient solution (Cowgill et al., 1989). before enriched with 25,50 , and 75 $\mathrm{mg} / \mathrm{L}$ concentration of cadmium $\left(\mathrm{Cd}\left(\mathrm{NO}_{3}\right)_{2}\right.$, Sigma, St. Louis, MO). All the concentrations were calculated based on the individual element versus their compound form. Plant sampling was carried out on 1, 3,5 and 7 days intervals.

\section{Antioxidant enzymes (APX \& POD)}

The activities of the tested antioxidant enzymes were assayed using the method of (Nakano and Asada, 1981). (EC 1.11.1.11) for APX, and those of (Wakamatsu and Takahama, 1993). (EC 1.11.1.7) for POD. In reference to control, the relative activity of the two enzymes calculated using the extinction coefficient $26.6 \mathrm{mM}^{-1} \mathrm{~cm}^{-1}$ and 2.8 $\mathrm{mM}^{-1} \mathrm{~cm}^{-1}$ for APX and POD, respectively.

\section{Protein Electrophoresis (SDS-PAGE)}

SDS-PAGE of total proteins in control and treated plant samples was carried out according to the method of (Laemmli, 1970). The resulting gels were scanned using Olympus camera model No C-7070. Protein bands were assigned in reference to protein marker (Fermentas, PageRuler ${ }^{\mathrm{TM}}$ Unstained protein Ladder \#SM0661, $10 \mathrm{kDa}$ to 200 $\mathrm{kDa}$ ), and analyzed to determine their molecular weight using BioDoc Analyze, Biometra 2006 program Version 2.49.8.1. Statistical analysis

Two-way ANOVA of SPSS 15.0 computer program was used to test the significant difference among means of the triplicate tested parameters at $P<0.01,0.001$. Regression coefficient computed to determine the relationships between the relative activity of antioxidant enzymes and both $\mathrm{Cd}$-concentration and exposure time.

\section{Results}

The relative activity of antioxidant enzymes (APX, POD) of studied plant species was comparatively lower in controlled conditions as compared to those grown in the presence of $\mathrm{Cd}^{+2}$. Under conditions of the present study, short 
duration of $\mathrm{Cd}^{+2}$-exposure and low $\mathrm{Cd}^{+2}$ concentration induced increase in activities of the two-antioxidant enzymes, Meanwhile with the long duration and high $\mathrm{Cd}^{+2}$ and vice versa (Fig. 1). The interactions between Cd-concentration and time of exposure appeared to have significant effect $(P<0.01)$ on the relative activities of the twoantioxidant enzymes. POD attained its maximum relative activity when the studied species treated with $50 \mathrm{mg} / \mathrm{L}-\mathrm{Cd}^{+2}$ at 5 -days exposure. It is being $1125 \%$ and $657.4 \%$ for $C$. demersum and $M$. spicatum, respectively (Fig 1a). After 7-day exposure to $75 \mathrm{mg} / \mathrm{L}$ $\mathrm{Cd}^{+2}$, the POD activity reached its minimum value in $C$. demersum $(932.44 \%)$ and $M$. spicatum (355.55\%). APX enzyme (Fig 1b) showed its maximum relative activity value of $440 \%$ at 5 -day exposure and $25 \mathrm{mg} / \mathrm{L}$ $\mathrm{Cd}^{+2}$ in C. demersum, and $848.48 \%$ at 3-day exposure and $50 \mathrm{mg} / \mathrm{L}-\mathrm{Cd}^{+2}$ in M. spicatum. On the other side, the relative activity of APX started to decrease at $50 \mathrm{mg} / \mathrm{L}-\mathrm{Cd}^{+2}$, exhibiting significantly different patterns $(P$ $<0.001)$ in relation to time of exposure and plant species. It attained its minimum value of $40 \%$ in $C$. demersum and $381.81 \%$ in $M$. spicatum at 7-day exposure.

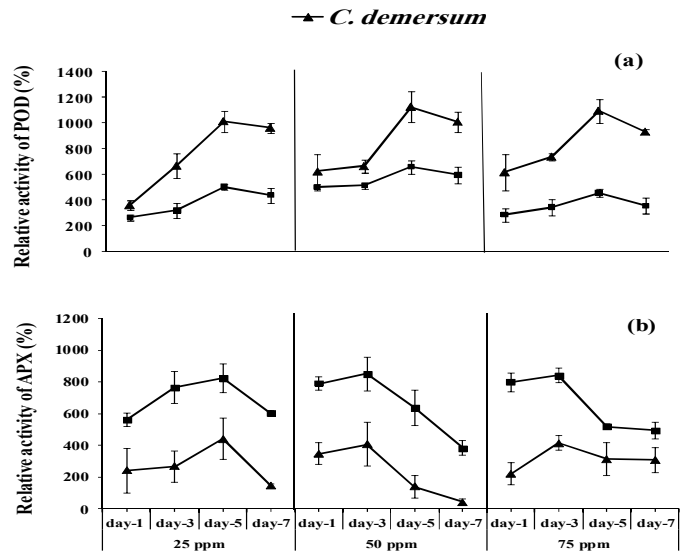

Figure 1: Changes in relative activity of antioxidant enzymes, (a) POD and (b) APX in $C$. demersum and $M$. spicatum treated with different $\mathrm{Cd}$ concentrations during the experiment duration.
The electrophoretic pattern of protein analysis in $C$. demersum is shown in Figure (2a). Compared to the control, the low $\mathrm{Cd}^{+2}$ concentration $(25 \mathrm{mg} / \mathrm{L})$ was found to simulate the synthesis of new polypeptides of high molecular weight $(138,127,112,109$ and $100 \mathrm{kDa}$ ), which they disappeared on the 5 -day of $\mathrm{Cd}^{+2}$-exposure. In addition, new lower molecular weight polypeptides $(67,37$, 32,16 and $15 \mathrm{kDa}$ ) appeared since the first day in all $\mathrm{Cd}^{+2}$-concentrations and disappeared on the seventh day of exposure. The noticeable feature was the absence of 38 $\mathrm{kDa}$ band in the profiles of all treated plants, which coupled with the appearance of chlorosis, and stem and leaf disintegration (Fig 3).

M. spicatum electrophoretic pattern (Fig 2b) exhibits close similarity between control and treated plants in their contents of proteins. All the detected polypeptides were of the low molecular weights that include 67 , 64, 61, 57, 39 and $34 \mathrm{kDa}$ polypeptides and appeared on the day 3 and disappeared on the day 7 of $\mathrm{Cd}^{+2}$-exposure in all set of experiment. Generally, in both macrophytes studies, increasing of $\mathrm{Cd}^{+2}$-concentration influenced the density of protein bands, while long exposure time induced the disappearance of these bands as compared to control. 


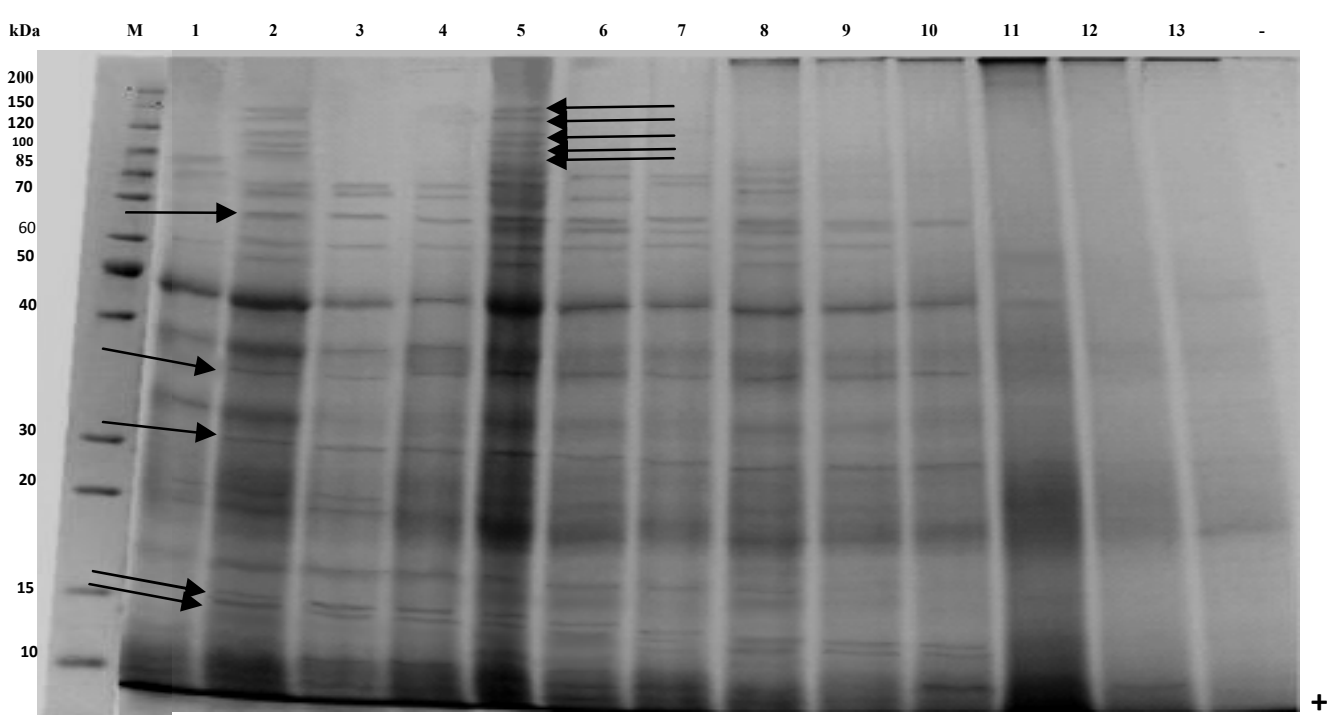

(a)

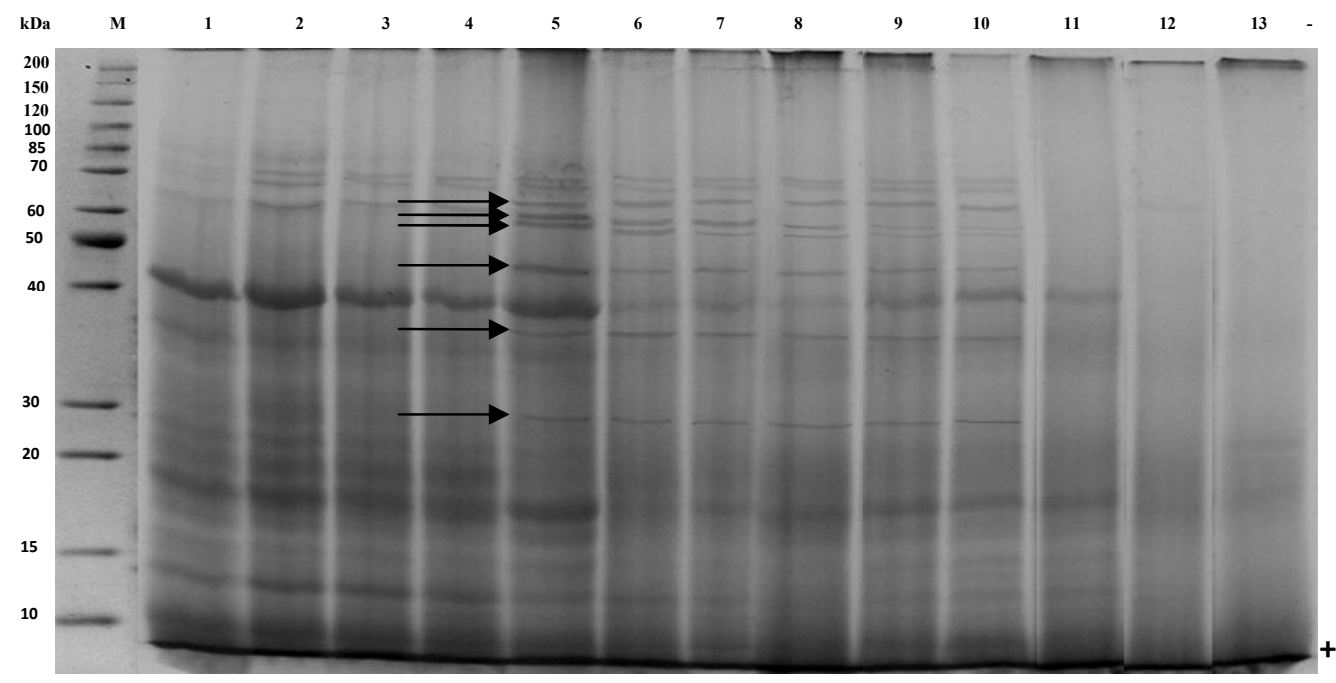

(b)

Figure 2: Protein banding patterns of C. demersum a) and $M$. spicatum b) under different Cdconcentrations and exposure time. $\mathrm{M}=$ markers, Lane 1: control. Lane 2, 5, 8, \&11 represent protein banding pattern at $1,3,5 \& 7$ days of $25 \mathrm{mg} / \mathrm{L} \mathrm{Cd}$ treatment, respectively. Lane 3, 6, 9 \&12 represent protein banding pattern at $1,3,5 \& 7$ days of $25 \mathrm{mg} / \mathrm{L} \mathrm{Cd}$ treatment, respectively.

Lane 4, 7, $10 \& 13$ represent protein banding pattern at $1,3,5 \& 7$ days of 50 $\mathrm{mg} / \mathrm{L} \mathrm{Cd}$ treatment, respectively. The arrows indicate appearance of new bands.
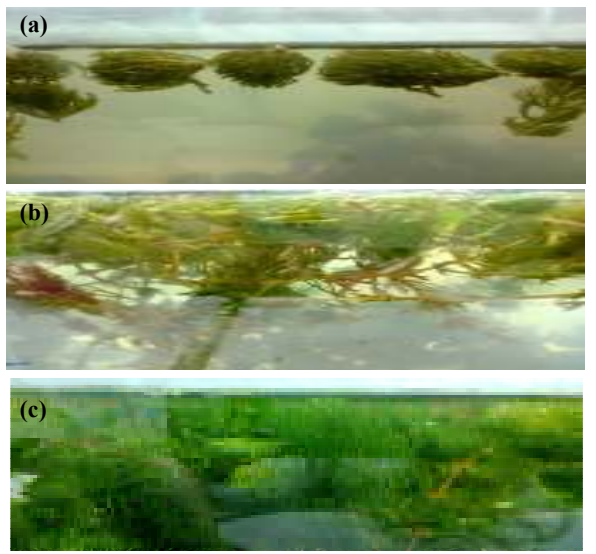

Figure. 3: Morphological changes in demersum induced by $\mathrm{Cd}$ stress: disintegration, (b) chlorosis, and (c) control.

\section{Discussion}

The results of present study clearly revealed an induction of the antioxidant enzymes (POD\& APX) upon exposure to different $\mathrm{Cd}^{+2}$ concentrations. The protective mechanisms by plants to scavenge free radicals include several antioxidative enzymes as glutathione reductase, peroxidase and ascorbic acid oxidase (Chen et al., 2000). The increase of POD activity as indicator of heavy metal stress was reported by many studies (MacFarlance and Burchett, 2001; Markkola et al., 2002; Baycu et al., 2006; Wang et al., 2010). suggests its role in the detoxification of $\mathrm{H}_{2} \mathrm{O}_{2}$. APX found to be more pronounced in M. spicatum (4-8 fold of control) in comparison to $C$. demersum. (Van Assche and Clijsters, 1990), have reported (a) such increase in the relative activity and 
concluded that the extent of increase varied with metal ion, metal concentration, the enzyme tested and plant species. In this work, the changes in antioxidant enzyme activities in response to heavy metal stress appeared to be dependent on metal concentration. Activities of these enzymes might increase in order to cope with the oxidative stress imposed by heavy metals on plants, as was repeatedly found in other experiments (Thomas et al., 1999; Radotic et al., 2000; Shah et al., 2001; Ianelli et al., 2002; El-Khatib et al., 2004; Baycu, et al., 2006). Alternatively, they might be diminished if the toxic effects of higher concentrations of heavy metals were greater than can be tolerated and combated by the antioxidant enzymes, as is the case in the present experiment. The decreases in antioxidant enzyme activities may result in the accumulation of reactive oxygen species, which can cause severe damage to plants; thus leading to the recorded stem disintegration in $C$. demesum with all $\mathrm{Cd}$ treatments on the 3-day exposure. the activity of the tested antioxidant enzymes in the studied aquatic species varied significantly $(P<0.01)$ among $C d$-treatments, where increase in $\mathrm{Cd}$ - concentration coupled with an initial increase of their activities and subsequent Cd-treatments caused a decline in the activity. This suggesting that the generated $\mathrm{H}_{2} \mathrm{O}_{2}$ increased to some extent that exceeds the elimination ability of these enzymes, the $\mathrm{H}_{2} \mathrm{O}_{2}$ as well as other oxyradicals can inversely insult the enzymes, making them inactivated and suffering oxidative stress.

The present study explained that $\mathrm{Cd}$ exposure induced the synthesis of a considerable number of stress proteins of different molecular mass in the two studied species. The density of protein bands in both studied species appears to be affected by $\mathrm{Cd}$ concentration and time of exposure. In comparison with control, the treated plants exhibited protein patterns of their owner depending on the plant species and Cdconcentration. The disappearance of some polypeptides and the de novo synthesis of others, in response to $\mathrm{Cd}^{+2}$ treatments, indicated that such treatments are highly effective in causing a major re-shuffle of the protein profiles of the two studied species. Protein synthesis in $C$. demersum appears to be more sensitive to cadmium exposure than that of M. spicatum. As cited in (UniProtKB/Swiss-Prot database, 2011), 38kDa polypeptide (Plastid-encoding protein) play role in PSII as electron donor and affect the formation of chlorophyll and pheophytin. Thus, its disappearance may be the reason for the observed chlorosis in the treated plants. In agreement with our results, (Prasad et al., 2009). found that $C$. demersum plants showed leaf and tissue disintegration, chlorosis, and survived for 7 days, when they exposed to $\mathrm{Cd}$. The detected lower molecular weight proteins in $M$. spicatum under $\mathrm{Cd}$ stress were not reported in the literatures. While polypeptides of $15,16,32 \mathrm{kDa}$ in $C$. demersum were reported previously as photosystem $\mathrm{Q}(\mathrm{B})$ protein family (UniProtKB/Swiss-Prot database, 2011), polypeptides of 37 and $67 \mathrm{kDa}$ is the first time to be reported here in the present study. Therefore, further studies are needed to reveal the mechanisms of these polypeptides at molecular levels for regulating the $\mathrm{Cd}$ induced stress in these macrophytes.

\section{References:}

Baycu, G., Tolunay, D., Özden, H., Günebakan, S. (2006). Ecophysiological and seasonal variations in $\mathrm{Cd}, \mathrm{Pb}, \mathrm{Zn}$, and $\mathrm{Ni}$ concentrations in the leaves of urban deciduous trees in Istanbul. Environ Pollut. 143: 545-554.

Boominathan, R. and Doran, P.M. (2003). Cadmium tolerance and antioxidative defenses in hairy roots of thecadmiumhyperaccumulator Thlaspi caerulescens. Biotechnol. Bioeng. 83: 158-167.

Chen, M., Chau, L., Ching, K. (2000). Oxidative stress in copper-treated rice roots. Bot. Bull. Acad. Sin. 41: 99-103.

Cowgill, U.M., Milazzo, D.P. (1989). "The culturing and testing of two species of duckweed," Aquatic Toxicology and Hazard Assessment: 12th Volume, ASTM STP 1027, U.M. Cowgill and L.R. Williams, Eds. American Society for Testing and materials, Phila., : 379-391.

El-khatib, A.A. and Elsawaf, N. (2001). Physiotoxicity of air particulate Pollutants (Dust) on the urban trees BULL.FAC.SCI.,ASSIUT UNIV. 30 (2D): 183-193.

El-khatib, A.A., Faheed, F.A., Azooz, M.M. (2004). physiological response of Eucalyptus rostrata to heavy metal air 
pollution. El- Minia science Bulletin Egypt, 15(2): 429-451.

Foyer, C.H., Lelandais, M., Kunert, K.J. (1994). Photooxidative stress in plants. Physiol. Plantarum 92: 696-717.

Gill, S.S., Khan, N.A., Anjum, N.A., Tuteja, N. (2011). Amelioration of cadmium stress in crop plants by nutrients management: Morphological, physiological and biochemical aspects. Plant Stress 5 (Special Issue 1): 1-23

Gratão, P.L., Polle, A., Lea, P.J., Azevedo, R.A. (2005). Making the life of heavy-metal stressed plants a little easier. Funct. Plant Biol. 32: 481-494.

Holan, Z.R. and Volesky, B. (1994). Biosorption of lead and nickel by biomass of marine algae, Biotechnol. Bioeng. 43: 1001-1009.

Ianelli, M.A., Pietrini, F., Fiore, L., Petrilli, L., Massacci, A. (2002). Antioxidant response to cadmium in Phragmites australis plants. Plant Physiol. Biochem. 40: 977982.

Khan, N.A., Singh, S. (2008). (Eds.), Abiotic Stress and Plant Responses, IK International, New Delhi,

Laemmli, U.K. (1970). Cleavage of structural proteins during the assembly of the head of bacteriophage T4. Nature (London) 227: 680-685.

Ma, J.F., Ueno, D., Zhao, F.J., McGrath, S.P. (2005). Subcellular localization of $\mathrm{Cd}$ and $\mathrm{Zn}$ in the leaves of a Cd-hyperaccumlating ecotype of Thlaspi caerulescens. Planta,220: 731-736.

MacFarlane, G.R., Burchett, M.D. (2001). Photosynthetic pigments and peroxidase activity as indicators of heavy metal stress in the grey mangrove, Avicennia marina (Forsk) Vierh. Marine Pollution Bulletin 42 (3): 233-240.

Markkola, A., Tarvainen, O., Ahonen-Jonnarth, U., Stro“mmerr, R. (2002). Urban polluted forest soils induce elevated roots peroxidase activity in Scots pine (Pinus sylvestris L.) seedlings. Environmental Pollution 116: 273-278.

Nakano, Y. and Asada, K. (1981). Hydrogen peroxide is scavenged by ascorbate specific peroxidase in spinach chloroplasts. Plant and Cell Physiology, 22: $867-880$.

Panda, S.K. and Choudhury, S. (2005). Chromium stress in plants. Braz. J. Plant Physiol. 17: 95-102.

Prasad, M.N.V., Aravind, P., Malec, P., Waloszek, A., Strzałka, K. (2009). Zinc protects Ceratophyllum demersum L. (free-floatinghydrophyte) against reactive oxygen species induced by cadmium
Journal of Trace Elements in Medicine and Biology 23 : 50-60

Radotic, K., Ducic, T., Mutavdzic, D. (2000). Changes in peroxidase activity and isozymes in spruce needles after exposure to different concentrations of cadmium. Environ. Expt. Bot. 44: 105-113.

Ralph, P.J. and Burchett, M.D. (1998). Photosynthetic response of Halophila ovalis to heavy metal stress. Environ. Pollut. 103: 91-101.

Salt, D.E., Prince, R.C., Baker, A.J.M., Raskin, I., Pickering, I.J. (1999). Zinc ligands in the metal hyperaccumulator Thlaspi caerulescens as determined using X-ray absorption spectroscopy. Environ. Sci. Techol. 33: 713-717.

Sandalio, L.M., Dalurzo, H.C., Gómez, M., Romero-Puertas, M.C., del Rio, L.A. (2001). Cadmium-induced changes in the growth and oxidative metabolism of pea plants. J. Exp. Bot. 52: 2115-2126.

Sanita diToppi, L. and Gabbrielli, R. (1999). Response to cadmium in higher plants. Environmental and Experimental Botany; 41: $105-30$.

Schiewer, S. and Volesky, B. in: D.R. Lovely (Ed.), (2000). Environmental MicrobeMetal Interactions, ASM Press, Washington, DC, pp. 329-362.

Shah, K., Kumar, R.G., Verma, S., Dubey, R.S. (2001). Effect of cadmium on lipid peroxidation, superoxide anion generation and activities of antioxidant enzymes in growing rice seedlings. Plant Sci. 161: 1135-1144.

Singh, S., Anjum, N.A., Khan, N.A., Nazar, R. (2008). Metal-binding peptides and antioxidant defence system in plants: significance in cadmium tolerance. In: N.A. Khan, S. Singh, (Eds.) Abiotic Stress and Plant Responses, IK International, New Delhi, pp. 159-189.

Tamás, L., Dudíková, J., Durceková, K., Huttová, J., Mistrík, I., Zelinová, V. (2008). The impact of heavy metals on the activity of some enzymes along the barley root. Environ. Exp. Bot. 62: 86-91.

Thomas, D.J., Thomas, J.B., Prier, S.D., Nasso, N.E., Herbert, S.K. (1999). Iron superoxide dismutase protects against chilling damage in the cyanobacterium Synechococcus species PCC7942. Plant Physiology 120: 275-282.

Tuteja, N. (2007). Mechanisms of high salinity tolerance in plants, Meth. Enzymol.: Osmosens. Osmosignal. 428: 419-438.

Ueno, D., Ma, J.F., Iwashita, T., Zhao, F.J., McGrath, S.P. (2005). Identification of the form of $\mathrm{Cd}$ in the leaves of a superior $\mathrm{Cd}$ - 
accumulating ecotype of Thlaspi caerulescens using 113Cd NMR. Planta 221: 928-936.

UniProtKB/Swiss-Prot

http://samul.org/main/uniprot/species/442 8page

Van Assche, F., and Clijsters, H. (1990). Effects of metals on enzyme activity in plants. Plant Cell Environ 13: 195-206.

Vitória, A.P., Lea, P.J., Azevedo, R.A. (2001). Antioxidant enzymes responses to cadmium in radish tissues. Phytochemistry 57: 701-710.

Wakamatsu, K. and Takahama, U. (1993). Changes in the peroxidase activity and in peroxidase enzymes in carrot callus. Physiologia Planatrum 88: 167-171

Wang, J., Weihua, Li., Chongbang Zhang., Shisheng, Ke. (2010). Physiological responses and detoxific mechanisms to $\mathrm{Pb}$, $\mathrm{Zn}, \mathrm{Cu}$ and $\mathrm{Cd}$ in young seedlings of Paulownia fortunei Journal of Environmental Sciences, 22(12): 19161922

Wojcik, M., Skorzyn' ska-Polit, E., Tukiendorf, A. (2006). Organic acid accumulation and antioxidant activities in Thlaspi caerulescens under $\mathrm{Zn}$ and $\mathrm{Cd}$ stress. Plant Growth Regul. 48: 145-155.

Wojcik, M., Vangronsveld, J., D'Haen, J., Tukiendorf, A. (2005). Cadmium tolerance in Thlaspi caerulescens II. Localization of cadmium in Thlaspi caerulescens. Environ. Exp. Bot. 53: 163-171.

Yu, Q., Matheickal, J.T., Kaewsarn, P. (1999). Heavy metal uptake capacities of common marine macro-algal biomass, Water Res. $33: 1534-1537$.

قد تم زراعة نوعين من النباتات المائية نبات السيراتوفيلم (Ceratophyllum demersum) ونبات الميروفيلم في نظام الزراعة المائية لتحليل الانزيمات المضادة للأكسدة، وتحليل طرز البروتين (Myriophyllum spicatum)

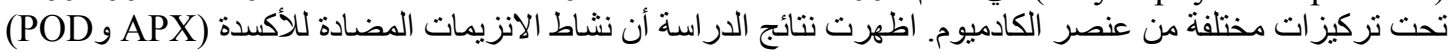

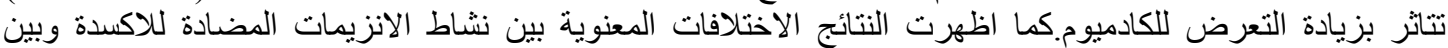

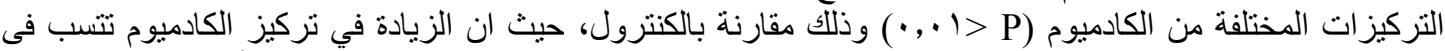

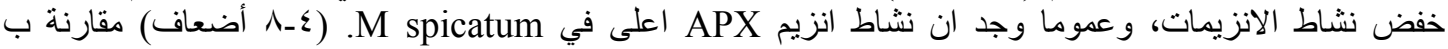

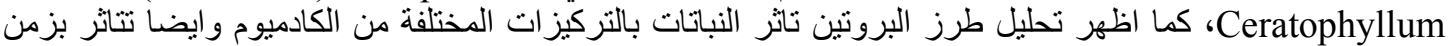

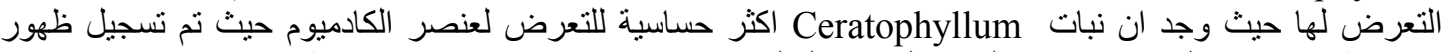
38kDa مجموعة جديدة من البروتينات ذات الوزن الجزئى العالى فى تركيز 25 mg/L Cd بالاضافة لاختفاء بروتين تهنين من جميع المعالجات. 